\title{
PENGARUH TEKANAN KERJA TERHADAP KINERJA KARYAWAN PADA CV. TRIMULYA DI BANDAR LAMPUNG
}

\author{
Usnawati $^{(1)}$, Ahiruddin $^{(2)}$, Tiar Mirnasari ${ }^{(3)}$ \\ Fakultas Ekonomi Universitas Sang Bumi Ruwa Jurai \\ usnawati010@gmail.com,ahiruddin@fe.saburai.ac.id,tiar.mirnasari@fe.saburai.ac.id
}

\begin{abstract}
Abstrak. Tekanan yang dialami para karyawan di CV. Trimulya baik itu terlalu rendah atau terlalu tinggi dapat berpengaruh pada tingkat kinerja di dalam bekerja. Bagi seorang pemimpin, tekanan-tekanan yang diberikan kepada seorang karyawan haruslah dikaitkan dengan apakah tekanan yang ditimbulkan oleh tekanan-tekanan tersebut masih dalam keadaan wajar. Kinerja para karyawan di CV. Trimulya perlu dicermati secara sistematis perkembangannya, sehingga dapat meningkatkan perilaku kerja karyawan, dan jika kinerja para karyawan menurun. Karena kinerja (performance) adalah hasil dari interaksi antara kinerja, kemampuan (abilities), dan peluang (oppurtunities). Teknik pengumpulan data yang digunakan dalam penelitian ini adalah observasi, wawancara dan kuesioner. Adapun populasi dalam penelitian ini adalah seluruh karyawan CV. Trimulya yang berjumlah 42 karyawan. Adapun teknik analisis dalam penelitian ini adalah rumus regresi linier sederhana. Berdasarkan hasil analisis diperoleh nilai t hitung sebesar 38,569 nilai tersebut jika dibandingkan dengan $\mathrm{t}$ tabel dimana $\mathrm{dk}=\mathrm{n}-2$ yaitu $42-2=40$ dengan taraf kesalahan $5 \%$ nilai $\mathrm{t}$ tabel adalah 2,020 dengan nilai sig $<0.05$. Hal ini berarti hipotesis alternatif Ha diterima dan Ho ditolak. Artinya ada pengaruh yang positif dan signifikan antara tekanan kerja terhadap kinerja karyawan pada CV. Trimulya.
\end{abstract}

Kata kunci: Karyawan, Kinerja, Pengaruh, Tekanan.

\section{PENDAHULUAN}

Ada beberapa alasan mengapa masalah tekanan yang berkaitan dengan organisasi perlu diangkat kepermukaan pada saat ini. Diantaranya adalah masalah tekanan adalah masalah yang akhir-akhir ini hangat dibicarakan dan posisinya sangat penting dalam kaitannya dengan produktivitas kerja karyawan dan Kinerja karyawan. Selain dipengaruhi oleh faktor-faktor (tekanansor) yang bersumber dari luar organisasi, tekanan juga banyak dipengaruhi oleh faktor-faktor yang berasal dari dalam organisasi.

Keadaan ini tentu saja menuntut energi pegawai yang lebih besar dari yang sudahsudah. Sebagai akibatnya, pengalamanpengalaman yang disebut tekanan dalam taraf yang cukup tinggi menjadi semakin terasa. Masalah-masalah ini pada dasarnya sering dikaitkan dengan pengertian tekanan yang terjadi dilingkungan pekerjaan, yaitu dalam pengertian tekanan yang terjadi dilingkungan pekerjaan, yaitu dalam proses interaksi antara seorang karyawan dengan aspek-aspek pekerjaannya. Jika suatu pekerjaan yang diterima tidak sesuai dengan minat, pendidikan, kemampuan dan pengalamannya, maka seorang karyawan tidak dapat melakukan tugasnya secara maksimal.

Hal ini salah satunya dapat disebabkan karyawan tidak mengetahui secara jelas atau kekurangan informasi mengenai tujuan kerja tanggung jawab terhadap pekerjaan dan perannya. Tekanan yang dialami para karyawan di CV. Trimulya baik itu terlalu rendah atau terlalu tinggi dapat berpengaruh pada tingkat kinerja di dalam bekerja. Bagi seorang pemimpin, tekanan-tekanan yang diberikan kepada seorang karyawan 
haruslah dikaitkan dengan apakah tekanan yang ditimbulkan oleh tekanan-tekanan tersebut masih dalam keadaan wajar.

Tekanan yang berlebihan akan menyebabkan karyawan tersebut frustasi dan dapat menurunkan kinerjanya, sebaliknya tekanan yang terlalu rendah menyebabkan karyawan tersebut tidak terkinerja untuk berprestasi. Adapun tekanan yang dapat mekinerja karyawan sehingga karyawan dapat bekerja lebih baik lagi. Setiap karyawan bekerja sesuai dengan tugasnya di dalam organisasi, artinya setiap tenaga kerja mempunyai tugasnya yang harus ia lakukan sesuai dengan aturanaturan yang ada dan sesuai dengan yang diharapkan oleh perusahaannya.

Masalah-masalah ini pada dasarnya sering dikaitkan dengan pengertian tekanan yang terjadi dilingkungan pekerjaan, yaitu dalam pengertian tekanan yang terjadi dilingkungan pekerjaan, yaitu dalam proses interaksi antara seorang karyawan dengan aspek-aspek pekerjaannya. Jika suatu pekerjaan yang diterima tidak sesuai dengan minat, pendidikan, kemampuan dan pengalamannya, maka seorang karyawan tidak dapat melakukan tugasnya secara maksimal. Hal ini salah satunya dapat disebabkan karyawan tidak mengetahui secara jelas atau kekurangan informasi mengenai tujuan kerja tanggung jawab terhadap pekerjaan dan perannya.

CV. Trimulya dengan kinerja organisasi yang efektif dan efisien, dengan dilakukannya penilaian kinerja aspek keuangan ini, maka segala pengambilan keputusan dapat ditelaah apakah sudah dilakukan secara tepat dan objektif. Hal ini, juga berguna untuk mengetahui dan mengevaluasi pelaksanaan kinerja dan membandingkan dengan rencana kerja serta melakukan tindakan untuk memperbaiki kinerja periode berikutnya.

Tekanan yang dialami para karyawan di CV. Trimulya baik itu terlalu rendah atau terlalu tinggi dapat berpengaruh pada tingkat kinerja di dalam bekerja. Bagi seorang pemimpin, tekanan-tekanan yang diberikan kepada seorang karyawan haruslah dikaitkan dengan apakah tekanan yang ditimbulkan oleh tekanan-tekanan tersebut masih dalam keadaan wajar.

Selain itu kinerja para karyawan di CV. Trimulya perlu dicermati secara sistematis perkembangannya, sehingga dapat meningkatkan perilaku kerja karyawan, dan jika kinerja para karyawan menurun. Karena kinerja (performance) adalah hasil dari interaksi antara kinerja, kemampuan (abilities), dan peluang (oppurtunities).

Keberhasilan seseorang dalam suatu pekerjaan ditentukan oleh tiga faktor utama. Pertama, ia harus memiliki kemampuan untuk mengerjakan pekerjaan tersebut, suatu kemampuan yang merupakan kombinasi dari kemampuan alami yang dibangun melalui pendidikan dan pelatihan. Kedua, ia harus mempunyai alat yang tepat untuk pekerjaan tersebut. Ketiga, ia juga harus memiliki dorongan atau kinerja untuk melakukan pekerjaan tersebut.

Dalam menjalankan pekerjaannya karyawan CV. Trimulya masih merasakan tekanan-tekanan dalam bekerja, tekanan tersebut disebabkan oleh beberapa faktor diantaranya; harus menyelesaikan pekerjaan dengan waktu yang mendesak, tuntutan kerja yang tinggi, pola kepemimpinan yang belum menekankan kemampuan manajerial seorang pemimpin, otoritas yang tidak memadai sehingga dapat menimbulkan tekanan kerja, sering terjadinya konflik kerja antara karyawan, perbedaan nilai antara karyawan dengan pimpinan yang mengalami tekanan dalam kerja meliputi penyelesaian selisih faham yang terjadi dengan atasan, ketidak cocokan sistem kerja yang diberikan, dan kenyamanan dengan gaya kepemimpinan atasan. Faktorfaktor tersebut akhir-akhirnya dapat menyebabkan kinerja akan merosot dan tidak optimal. 
Berikut ini adalah jumlah karyawan CV. Trimulya periode bulan September sampai dengan Desember 2018. Tingkat kehadiran karyawan sampai dengan Desember 2018 cukup rendah hal ini dimungkinkan karena adanya tekanan kerja karyawan yang berdampak pada kinerja karyawan, sehingga akan menjadi kendala dalam suatu pekerjaan yang menjadi tangung jawab setiap karyawan.

Selain tingkat kehadiran karyawan, penilaian prestasi juga dapat dijadikan motivasi kerja untuk meningkatkan kinerja karyawan, hal ini bertujuan untuk menjamin objektifitas pembinaan karyawan yang dilakukan berdasarkan sistem prestasi kerja dan sistem karier yang dititik beratkan pada sistem prestasi kerja. Berdasarkan uraian tersebut, maka penulis tertarik untuk mengadakan penelitian lebih lanjut dengan judul : "Pengaruh Tekanan Kerja Terhadap Kinerja Karyawan Pada CV. Trimulya Di Bandar Lampung”.

\section{KAJIAN TEORI}

\section{Pengertian Tekanan Kerja}

Tekanan kerja adalah suatu kondisi dinamis dimana seorang individu dihadapkan pada peluang, tuntutan atau sumber daya yang terkait dengan apa yang dihasratkan oleh individu itu dan yang hasilnya dipandang tidak pasti dan penting. Tekanan lebih sering dikaitkan dengan tuntutan (demand) dan sumber daya (resources). Tekanan sendiri tidak selalu buruk, meskipun biasanya dibahas dalam konteks negatif, tekanan juga memiliki nilai positif.

Tekanan merupakan sebuah peluang ketika hal ini menawarkan potensi hasil. Sebagian tekanan bisa positif, dan sebagian lagi bisa negatif. Dewasa ini, para peneliti berpendapat bahwa tekanan tantangan, atau tekanan yang menyertai tantangan dilingkungan kerja (seperti memiliki banyak proyek, tugas dan tanggung jawab), beroperasi sangat berbeda dari tekanan hambatan, atau tekanan yang menghalangi dalam mencapai tujuan (birokrasi, politik kantor, kebingungan terkait tanggung jawab bekerja) (Robbins dan Judge, 2008).

Menurut Fahmi (2013) Tekanan adalah keadaan yang menekan diri dan jiwa seseorang diluar batas kemampuannya, sehingga jika terus dibiarkan tanpa ada solusi maka ini akan berdampak pada kesehatannya. Menurut Rivai (2004) tekanan sebagai suatu istilah yang merangkumi stres, beban, konflik, keletihan ketegangan panik, perasaan gemuruh dan hilangnya daya. Tekanan kerja adalah suatu kondisi ketegangan yang menciptakan adanya ketidakseimbangan fisik dan psikis, yang mempengaruhi emosi, proses berfikir, dan kondisi seorang karyawan. Tekanan yang terlau besar dapat mengancam kemampuan seseorang untuk menghadapi lingkungan.

\section{Penanggulangan Tekanan Kerja}

Mengingat tekanan kerja dapat mengakibatkan dampak yang buruk seperti yang sudah diuraikan diatas, maka perlulah dicari cara untuk penanggulangan tekanan kerja. Di dalam bukunya, Melayu S.P Hasibuan mengemukakan bahwa untuk mengetatasi tekanan dilakukan dengan pendekatan kejiwaan atau konseling. Konseling adalah pembahasan suatu masalah dengan seorang karyawan, dengan maksud pokok membantu karyawan tersebut agar dapat mengatasi masalah secara lebih baik, konseling bertujuan untuk membuat orang-orang menjadi lebih efektif dalam memecahkan masalah mereka.

Adapun fungsi dari konseling adalah sebagai berikut :

1. Pemberian nasihat, yaitu dengan meyakinkan karyawan dalam pelaksanaan serangkaian kegiatan yang diinginkan. 
2. Penentraman hati, yaitu dengan meyakinkan karyawan bahwa dia mampu untuk mengerjakan tugasnya asalkan dilaksanakan sungguhsungguh.

3. Komunikasi, yaitu melakukan komunikasi dua arah, formal dan informal, vertikal maupun horizontal dan umpan balik harus ditanggapi manajer secara positif serta diberikan penjelasan seperlunya.

4. Pengenduran ketegangan emosional, yaitu memberikan kesempatan bagi orang tersebut untuk mengemukakan problem yang dihadapinya secara gamblang dan jangan diinterupsi sampai dia selesai mengemukakannya.

\section{Pengertian Kinerja}

Setiap karyawan dalam organisasi dituntut untuk memberikan kontribusi positif melalui kinerja yang baik, mengingat kinerja organisasi tergantung pada kinerja karyawannya (Gibson, et all, 2010). Kinerja adalah tingkat terhadapnya para karyawan mencapai persyaratan pekerjaan secara efisien dan efektif (Simamora, 2006).

Menurut Dessler (2006) kinerja karyawan merupakan prestasi kerja, yakni perbandingan antara hasil kerja yang dapat dilihat secara nyata dengan standar kerja yang telah ditetapkan organisasi. Kemudian Robbins (2008) mendefinisikan kinerja yaitu suatu hasil yang dicapai oleh karyawan dalam pekerjaanya menurut kriteria tertentu yang berlaku untuk suatu pekerjaan.

Sedangkan Rivai (2009) kinerja diartikan kesediaan seseorang atau kelompok orang untuk melakukan suatu kegiatan, dan menyempurnakannya sesuai tanggung jawabnya dengan hasil seperti yang diharapkan.
Berdasarkan pengertian-pengertian kinerja dari beberapa pendapat diatas, dapat disimpulkan bahwa kinerja merupakan hasil kerja baik itu secara kualitas maupun kuantitas yang telah dicapai karyawan, dalam menjalankan tugas-tugasnya sesuai dengan tanggung jawab yang diberikan organisasi, dan hasil kerjanya tersebut disesuaikan dengan hasil kerja yang diharapkan organisasi, melalui kriteriakriteria atau standar kinerja karyawan yang berlaku dalam organisasi.

Berhasil tidaknya kinerja yang telah dicapai oleh organisasi tersebut di pengaruhi oleh tingkat kinerja karyawan secara individual maupun secara kelompok. Dengan asumsi semakin baik kinerja karyawan maka semakin baik pula kinerja organisasi. Dengan demikian organisasi perlu menetapkan tujuan kinerja karyawan.

\section{Indikator Kinerja}

Adapun indikator dari kinerja karyawan menurut Bernadine (dalam Mas'ud, 2010 : 77) adalah sebagai berikut:

1. Kualitas

Tingkat dimana hasil aktifitas yang dilakukan mendekati sempurna, dalam arti menyesuaikan beberapa cara ideal dari penampilan aktifitas ataupun memenuhi tujuan yang diharapkan dari suatu aktifitas.

\section{Kuantitas}

Jumlah yang dihasilkan dalam istilah jumlah unit, jumlah siklus aktifitas yang diselesaikan.

\section{Ketepatan}

Waktu Tingkat suatu aktifitas diselesaikan pada waktu awal yang diinginkan, dilihat dari sudut koordinasi dengan hasil output serta memaksimalkan waktu yang tersedia untuk aktifitas lain. 
4. Efektivitas

Tingkat penggunaan sumber daya manusia organisasi dimaksimalkan dengan maksud menaikan keuntungan atau mengurangi kerugian dari setiap unit dalam penggunaan sumber daya.

5. Kemandirian

Tingkat dimana seorang karyawan dapat melakukan fungsi kerjanya tanpa minta bantuan bimbingan dari pengawas atau meminta turut campurnya pengawas untuk menghindari hasil yang merugikan.

\section{METODE PENELITIAN}

\section{Objek Penelitian}

Objek penelitian ini adalah $\mathrm{CV}$. Sumber Trimulya beralamat di Jalan Teuku Cik Ditiro No. 129 di Bandar Lampung, dilaksanakan mulai bulan Mei sampai dengan Juli 2019.

\section{Metode dan Teknik Pengumpulan Data}

Dalam penelitian ini jenis data yang diperlakukan adalah :

a. Data Primer

Data primer merupakan data dasar yang akan diperoleh langsung tanpa perantara orang atau lembaga lain sebagai pihak ketiga. Data primer ini diperoleh dengan wawancara melalui responden dengan menggunakan daftar pertanyaan.

b. Data Sekunder

Data skunder merupakan data yang diperoleh melalui orang lain yang berhubungan dengan permasalahan yang dipecahkan. Data sekunder ini diperoleh melalui cara studi dokumenter yaitu mengumpulkan dan mempelajari brosurbrosur serta dokumen organisasi.
Adapun teknik yang digunakan dalam pengumpulan data adalah dengan :

1. Observasi, yaitu mengadakan survey atau pengamatan langsung kelokasi penelitian.

2. Interview atau wawancara, yaitu mengadakan tanya jawab langsung dengan pegawai.

3. Dokumentasi, yaitu mengumpulkan dan mencatat dokumentasi yang relevan.

4. Kuisioner, yaitu membuat pertanyaan yang berhubungan dengan varibael penelitian.

\section{Sampel dan Populasi}

Pengambilan sampel penelitian ini menggunakan teknik populasi dari karyawan CV. Trimulya di Bandar Lampung yang subjeknya kurang dari 100 maka diambil seluruhnya berjumlah 42 orang . Sebagaimana pendapat Arikunto Suharsimi (2010) menyatakan bahwa apabila subjeknya kurang dari 100 lebih baik diambil semua, tetapi subjeknya lebih dari 100, maka dapat diambil 10\%-15\% atau lebih.

\section{Metode Analisis Data}

Dalam penelitian ini digunakan metode kualitatif dengan desain deskriptif, yaitu penelitian yang memberi gambaran secara cermat mengenai individu atau kelompok tertentu tentang keadaan dan gejala yang terjadi (Koentjaraningrat, 2008).

Data yang diperoleh melalui penelitian lapangan dianalisis menggunakan analisis kuantitatif yang didasarkan pada analisis statistik untuk mengetahui pengaruh tekanan kerja $(\mathrm{X})$ terhadap kinerja $(\mathrm{Y})$.

Persamaan Regresi Linear Sederhana menentukan persamaan regresi linear sederhana untuk X : 


$$
Y=a+b X+e
$$

Keterangan:

$$
\begin{aligned}
& \mathrm{Y}=\text { Kinerja } \\
& \mathrm{a}=\text { Konstanta } \\
& \mathrm{b}=\text { Koefisien regresi } \mathrm{X} \\
& \mathrm{X}=\text { Tekanan kerja } \\
& \mathrm{e}=\text { Faktor kesalahan }
\end{aligned}
$$

Untuk mengetahui besarnya pengaruh, penghitungan koefisien korelasi tersebut kemudian dilanjutkan dengan Rumus Koefisien Determinasi atau Koefisien Penentu (KP):

$$
K P=(r)^{2} \times 100 \%
$$

Untuk menguji secara hipotesis secara parsial digunakan Uji t dengan rumus :

$$
t_{\text {hitung }}=\frac{r \sqrt{N-2}}{\sqrt{1-r^{2}}}
$$

Keterangan:

$$
\begin{array}{ll}
\mathrm{t}_{\text {hitung }} & =\text { Nilai } \mathrm{t} \\
\mathrm{r} & =\text { Koefisien Korelasi } \\
\mathrm{N} & =\text { Jumlah responden }
\end{array}
$$

Kriteria untuk Uji $t$ adalah sebagai berikut :

a) Jika $t_{\text {hitung }}>t_{\text {tabel }}$ maka Ha diterima dan Ho ditolak.

b) Jika $t_{\text {hitung }} \leq \mathrm{t}_{\text {tabel }}$ maka Ha ditolak dan Ho diterima.

\section{HASIL DAN PEMBAHASAN}

\section{Analisis Kuantitatif}

Dalam penelitian ini penulis mengambil judul "Pengaruh Tekanan Kerja Terhadap Kinerja Karyawan Pada CV. Trimulya Di Bandar Lampung", dengan jumlah responden 42 orang. Untuk memperoleh data dalam penelitian ini penulis menggunakan angket atau kuisioner.

Pembuatan angket atau kuisioner berdasarkan definisi operasional variabel yang penulis jabarkan dalam dua variabel yaitu variabel tekanan kerja dan kinerja karyawan. Dari variabel tersebut diberikan definisi operasionalnya dan selanjutnya ditentukan indikator yang akan diukur. Dari indikator ini kemudian dijabarkan menjadi butir-butir pertanyaan atau pernyataan. Untuk memudahkan penyusunan instrumen.

Untuk bisa mendapatkan indikatorindikator dari variabel yang diteliti, maka diperlukan wawasan yang luas tentang variabel yang diteliti dan teori-teori yang mendukungnya. Penggunaan teori untuk menyusun instrumen harus cermat agar diperoleh indikator yang valid, caranya dapat dilakukan dengan membaca berbagai referensi.

\section{Uji Validitas dan Reliabilitas}

Berdasarkan hasil uji validitas dapat diketahui bahwa dari tabel validitas instrumen tekanan kerja dan kinerja karyawan dapat disimpulkan bahwa nilai korelasi lebih besar dari pada $\mathrm{r}$ tabel dengan $\mathrm{dk}=\mathrm{n}-2=42-2=40$ yaitu 0,304 sehingga dapat digunakan dalam penelitian ini. Dari hasil perhitungan tersebut didapat nilai alpha cronbach lebih besar dari pada nilai kritisnya $(0.881>0,304)$ maka semua instrumen reliabel.

\section{Analisis Kuantitatif}

Untuk mengetahui bagaimanakah pengaruh tekanan kerja terhadap kinerja karyawan (data hasil angket lampiran 3) digunakan rumus regresi linier sederhana $\mathrm{Y}$ $=0,184+0,999$ X. $\alpha=0,184$ mempunyai makna jika tekanan kerja dianggap konstan maka kinerja karyawan sebesar 0,184 persen. $b=0,999$ mempunyai makna jika tekanan kerja ditingkatkan 1 persen, maka 
kinerja karyawan meningkat sebesar 0,999 persen. Berdasarkan keterangan diatas, dapat ditarik kesimpulan bahwa nilai koefisien Regresi variabel tekanan kerja memberikan kontribusi terhadap kinerja karyawan pada CV. Trimulya.

Dari hasil di atas, pada tabel Model Summary di dapat hasil $\mathrm{R}^{2}$ sebesar 0,974 , artinya ada penagruh tekanan kerja terhadap kinerja karyawan sebesar 97,4\%, sedangkan yang 2,6\% dipengaruhi oleh faktor lain. Kemudian pada tabel Coefficients, didapat nilai t hitung sebesar 38,569 nilai tersebut jika dibandingkan dengan $\mathrm{t}$ tabel dimana $\mathrm{dk}$ $=\mathrm{n}-2$ yaitu 42-2=40 dengan taraf kesalahan $5 \%$ nilai t tabel adalah 2,020 (Lampiran 4) dengan nilai sig $<0.05$. Hal ini berarti hipotesis alternatif $\mathrm{Ha}$ diterima dan $\mathrm{Ho}$ ditolak. Artinya ada pengaruh yang positif dan signifikan antara tekanan kerja terhadap kinerja karyawan pada CV. Trimulya.

Kinerja karyawan sangat diperukan dalam sebuah pekerjaan, karena apabila kinerja seorang karyawan baik, maka akan menghasilkan produktivitas kerja yang baik sehingga pekerjaan yang dikerjakan dapat diselesaikan dengan hasil yang memuaskan. Adanya faktor yang mempengaruhi baik buruknya kinerja seseorang yaitu bermacam-macam salah satunya tekanan kerja dari perusahaan, yaitu apabila karyawan merasakan tekanan kerja yang tinggi maka akan mengakibatkan kinerja yang kurang baik. Dari hasil analisis di atas, dapat diketahui bahwa terdapat pengaruh tekanan kerja terhadap kinerja CV. Trimulya.

\section{KESIMPULAN DAN SARAN}

\section{Kesimpulan}

Berdasarkan hasil dan pembahasan yang telah dilakukan dapat disimpulkan bahwa hasil $\mathrm{R}^{2}$ sebesar 0,974 , artinya ada penagruh tekanan kerja terhadap kinerja karyawan sebesar 97,4\%, sedangkan yang
2,6\% dipengaruhi oleh faktor lain. Kemudian pada tabel Coefficients, didapat nilai t hitung sebesar 38,569 nilai tersebut jika dibandingkan dengan $\mathrm{t}$ tabel dimana $\mathrm{dk}$ $=\mathrm{n}-2$ yaitu $42-2=40$ dengan taraf kesalahan $5 \%$ nilai t tabel adalah 2,020, dengan nilai sig $<0.05$. Hal ini berarti hipotesis alternatif $\mathrm{Ha}$ diterima dan Ho ditolak. Artinya ada pengaruh yang positif dan signifikan antara tekanan kerja terhadap kinerja karyawan pada CV. Trimulya.

\section{Saran}

Sehubungan dengan telah selesainya penelitian ini dan sebagai tindak lanjut dari kesimpulan yang penulis uraikan di atas, maka penulis ingin menyampaikan beberapa saran sebagai berikut :

1. Hendaknya pimpinan perusahaan lebih memperhatikan beban kerja karyawannya, sehingga karyawan tidak mengalami stres kerja dan tekanan kerja yang tinggi agar dapat bekerja dengan hasil yang maksimal.

2. Diharapkan pimpinan perusahaan dapat memberikan motivasi yang tinggi kepada karyawannya agar karyawan lebih bersemangat dan efektif dalam bekerja untuk menghasilkan produktivitas kerja yang tinggi.

\section{DAFTAR PUSTAKA}

Arikunto, Suharsimi. 2013. Teknik Penelitian. Jakarta: Elangga.

Faisal. 2005. Fasilitas Kerja. Jakarta: Agro Media.

Furchan, Arief. 2009. Statistik Deskriptif. Surabaya: Erlangga.

Ghozali. 2011. Manajemen Sumber Daya Manusia: Suatu pendekatan Mikro 
(dalam Tanya Jawab). Jakarta: Djambatan.

Ghozali, Imam. 2014. Uji Validitas. Yogyakarta: PT. Liberty.

Gujarati. 2011. Uji Hipotesis. Surabaya: Erlangga.

Hadi, Sutrisno. 2008. Sumbangan Efektif. Yogyakarta: PT. Liberty.

Nursalam. 2011. Jenis Perkerjaan.Jakarta: PT. Bumi Aksara.

Prasetyo, Rendi. 2015. Peningkatan Efisiensi Kerja Pegawai melalui Kerjasama Tim Pada Bagian Umum dan Kepegawaian Dinas Kesehatan Kota Semarang. Semarang: Universitas Negeri Semarang.

Sawyer, William. 2003. Teknologi dalam Perkerjaan. Jakarta: Agromedia.

Sedarmayanti. 2013. Sumber Daya Manusia dan Produktivitas Kerja. Bandung: Mandar Maju.

Sugiyono. 2011. Metode Penelitian Pendidikan: Pendekatan Kuantitatif, Kualitatif dan $R \& D$. Bandung: Alfabeta.

Sumoharjo. 2009. Struktur Bangunan. Jakarta: Elexmedia Komputindo.

Umar, Husein. 2011. Desain Penelitian MSDM dan Perilaku Karyawan. Jakarta: Rajawali Pers.

Usman, Husaini. 2011. Regresi Linear. Malang: Avveroes Press.

Yamin, Sofyan. 2011. Regresi dan Korelasi dalam Genggaman Anda. Jakarta: Salemba Empat. 